\title{
Knowledge of educators and dieticians on food and nutrition education in the school environment
}

\section{$(10$}

Conhecimentos de educadores e nutricionistas

sobre a educação alimentar e nutricional

no ambiente escolar

Alicinez Guerra ALBUQUERQUE

Cleide Maria PONTES 2

Mônica Maria OSÓRIO'

A B S T R A C T

\section{Objective}

The purpose of this qualitative study was to reveal the expertise of educators and dieticians on food and nutrition education in the school environment.

\section{Methods}

This study used a qualitative approach developed jointly by the Department of Education of the state of Pernambuco, Brazil, and a school in that state. The participants were seven teaching technicians, eight teachers, and thirteen dieticians. The information was collected by interview and submitted to thematic content analysis.

\section{Results}

Six themes emerged from the participants' statements: food and nutrition education as a guideline for eating correctly; the purpose of food and nutrition education as an instrument for promoting healthy eating habits; the school as a promoter and empowering environment for food and nutrition education; food and nutrition education as a pedagogical practice focused on the reality of students' eating habits; school agents' assignments and partnerships for food and nutrition education; lack of knowledge in the practice of food and nutrition education.

\footnotetext{
1 Universidade Federal de Pernambuco, Centro de Ciências da Saúde, Programa de Pós-Graduação em Nutrição. Av. Prof. Moraes Rego, 1235, Cidade Universitária, 50670-901, Recife, PE, Brasil. Correspondência para/Correspondence to: AG ALBUQUERQUE. E-mails: <alicinez@yahoo.com>; <alicinez.guerra@gmail.com>.

2 Universidade Federal de Pernambuco, Centro de Ciências da Saúde, Programa de Pós-Graduação em Enfermagem. Recife, PE, Brasil.
} 
292 | AG ALBUQUeRQUE et al.

\section{Conclusion}

The participants' knowledge on food and nutrition education is dichotomous, at times permeated by biological aspects, at other times by the social context. Although there are gaps in the knowledge of the subject, educators and dieticians consider themselves partners for the provision of food and nutrition education in school.

Indexing terms: Educator. Food and nutrition education. Dietician. School.

\section{R E S U M O}

\section{Objetivo}

Desvelar os conhecimentos de educadores e nutricionistas sobre a educação alimentar e nutricional no ambiente escolar.

\section{Métodos}

Este estudo, conduzido pela abordagem qualitativa, foi desenvolvido na Secretaria Estadual de Educação de Pernambuco e em uma escola deste estado. Os participantes foram sete técnicos de ensino, oito professores e treze nutricionistas. As informações foram coletadas por meio de entrevista e submetidas à análise de conteúdo temática.

\section{Resultados}

Das falas dos participantes, emergiram seis categorias temáticas: a educação alimentar e nutricional como regra de comer certo; a finalidade da educação alimentar e nutricional: promover hábitos alimentares saudáveis; a escola: um ambiente fomentador e potencializador da educação alimentar e nutricional; a educação alimentar e nutricional como prática pedagógica centrada na realidade alimentar do aluno; atribuições e parcerias dos atores escolares para a educação alimentar e nutricional; carência de conhecimento para a prática da educação alimentar e nutricional.

\section{Conclusão}

Os conhecimentos dos participantes sobre educação alimentar e nutricional são dicotômicos, ora apenas permeados pelos aspectos biológicos, ora considerando o contexto social. Ainda que existam lacunas no conhecimento da temática, os educadores e nutricionistas consideram-se parceiros na prática da educação alimentar e nutricional na escola.

Termos de indexação: Educador. Educação alimentar e nutricional. Nutricionista. Escola.

\section{INTRODUCTION}

Food and nutrition education may be understood as a strategy for building, forming, and sharing personal and group habits and attitudes regarding a healthy diet that aims to guarantee food and nutrition security and promote health. In this context, food and nutrition education has the role of producing and disseminating dietary knowledge that can help in the choice of healthy foods ${ }^{1}$.

Food has many dimensions, and the following stand out: the human right that allows food to be demanded given the understanding that the state has the obligation to provide it; the biological dimension covers the nutritional and sanitary aspects of foods for the proper functioning of the body to prevent diseases; the psychosocial and cultural dimensions cover food values and choices and the act of eating, including the rituals; the environmental dimension covers sustainable food production, availability and consumption; and the economic dimension refers to affordable food and the labor relationships associated with planting, harvesting, storing, transporting and selling foods ${ }^{2}$.

Food and nutrition education should extend to everyone, from children to the elderly, developing actions that pervade formal and informal education ${ }^{3}$. In formal education, the school environment stands out as an institution appropriate for the implementation of food and nutrition education, where the pedagogical 
practices required for the learning process and improvement of the quality of life occur ${ }^{4}$. The learning process has the function of forming citizens with a critical view of the world, individuals who are knowledgeable in the numerous subjects related to life and society, among them human food and nutrition.

Public schools also have the Programa Nacional de Alimentação Escolar (PNAE, National School Food Program). Some of its objectives are supplying healthy meals to the students and promoting food and nutrition education ${ }^{5}$. Food and nutrition education should be included in the learning and teaching process, pervading the school curriculum, approaching the theme in its dimensional complexity, and aiming to aid the development of healthy life practices, the creation of a food and nutrition security perspective, and health promotion ${ }^{6,7}$.

School curricula are guided by the Parâmetros Curriculares Nacionais (PCN, National Curricular Parameters), which consist of a reference of combined teaching-learning contents and objectives and cover, in addition to the mandatory disciplines, transversal themes (ethics, cultural plurality, environment, health, sexual orientation, work and general consumption). This cross-sectional nature of themes corresponds to the didactic aspects of interdisciplinarity 8,9 .

The teaching and learning process for food and nutrition education may follow the precepts of the liberating education concept conceived by Paulo Freire. This concept combines the student, educator, theme to be apprehended, and its social context and builds a multidimensional and interdisciplinary knowledge during the education process. Hence, liberating education provides problematization; it is capable of contributing to the development of awareness and motivation to transform reality and build knowledge to overcome the normalization of knowledge transmission ${ }^{10}$.

In the educational system, educators know and live daily with students in a simultaneous relationship of knowledge construction and exchange, so they have an important role in the configuration and establishment of food and nutrition education. The educator's knowledge is essential for effectively forming ideas in schools that promote food and nutrition education ${ }^{11}$. In schools, when dieticians interact with the school staff, they help to strengthen and disseminate food and nutrition education, since they are technically responsible for the PNAE ${ }^{5}$.

The promotion of food and nutrition education in school requires reflecting about this theme to improve its understanding and consequently expand the role of educators and dieticians. Given the importance and responsibility of these professionals in developing food and nutrition education actions in the educational system, the present study aims to unveil the knowledge of educators and dieticians on food and nutrition education in the school environment.

\section{METHODS}

This is a descriptive and exploratory study with a qualitative approach. This approach was chosen because it provides ways of unveiling people's universe of meanings and knowledge regarding the study object ${ }^{12}$.

This study was done at the State Department of Education of Pernambuco, located in the city of Recife (PE), and in a single school of the public state teaching network, the Escola Estadual Severino de Andrade Guerra located in the municipality of Machados, in the arid region of Pernambuco. This major school has 1,041 students. Elementary grades 1 through 8 have 426 students and 23 teachers, and high school grades 1 through 3 have 615 students and 32 teachers. This school was chosen because the PNAE works regularly in it, it has educators available for participating in the study, and it is located in a region whose economy is based on food production and sales, characterizing a region that stands out in the food and nutrition security dimensions ${ }^{13}$. 
Three groups of participants composed the study: the first group consisted of teaching technicians who work at the Administration of Educational Policies of Ensino Fundamental II (grades 6 through 9) of Pernambuco's State Department of Health. They plan the elementary and middle school curricula of state schools; the second group consisted of teachers that teach in the Ensino Fundamental /I of the school Escola Estadual Severino de Andrade Guerra; and the third group consisted of dieticians responsible for the PNAE of the public schools of the state working at the Regional Education Administrations. There are 17 Regional Education Administrations throughout the state of Pernambuco, each one covering a certain number of municipalities with state schools. The dieticians of the Regional Education Administrations visit the respective schools to develop and follow the activities related to the PNAE (menu planning and guidance, food handling monitoring, training of cooks and managers, and food and nutrition education, among others).

The inclusion criteria for the participants were: technical teaching educators of the Administration of Educational Policies of the Ensino Fundamental II (grades 6 through 9) of the State Department of Education, responsible for planning the school curriculum, with teaching experience; school teachers that taught Ensino Fundamental II classes of different disciplines, with various teaching degrees and at least five years of experience teaching public state school classes; and dieticians working at the Regional Education Administrations responsible for the PNAE in the schools of each administration. The participants were chosen based on their work in Ensino Fundamental II, since these grades have diverse school curricula and includes students aged 10 to 14 years, phase in which the cognitive and behavioral changes that will shape adult life begin.

The selection of the key participants was intentional. The number of participants was established by saturation, that is, when statements become repetitive and no new information emerges ${ }^{12,14}$. The sample totaled 28 participants: seven technical teaching educators from the Administration of Educational Policies of the State Department of Education, three dieticians from the Regional Education Administrations and eight teachers from the school Escola Estadual Severino de Andrade Guerra. The interviews with the technical teaching educators lasted on average 22 minutes; with the school teachers, 10 minutes; and with the dieticians, 16 minutes. The pilot study was done with six participants, two from each group. These subjects were not included in the sample because the instrument was reformulated.

Data were collected during individual interviews ${ }^{12}$ from May to July 2011. The interview used a guide with closed questions about demographic characteristics and formal education and training to define the participants' profiles, and one open question that guided the study analysis: according to your knowledge, what do you know about food and nutrition education in school? The interviews were done in private areas, recorded in MP4 format and fully transcribed.

The answers to the guiding question were submitted to thematic content analysis as proposed by Bardin ${ }^{15}$ : initially, the interviews were pre-analyzed, that is, they were skimmed and thoroughly read (text knowledge and analysis) for identifying the core meanings representative of the study object and guiding question; next, the core meanings were codified according to the similarity of their meanings, resulting in the creation of subcategories; finally, these thematic subcategories were re-codified to build the thematic categories of the study.

The thematic categories were interpreted in the light of the PNAE ${ }^{5,6}, \mathrm{PCN}$ of Elementary Education ${ }^{8,9}$ and theoretical bases of liberating education ${ }^{10}$.

The project was approved by the Universidade Federal de Pernambuco Center of Health Sciences' Human Research Ethics Committee under protocol number 485/10, according to the precepts established by 
Resolution 196/96 ${ }^{16}$. Anonymity was guaranteed by assigning a letter to each participant ( $D$ for Dietician, $T$ for Teacher and $E$ for Technical Teaching Educator) followed by a number corresponding to the number of the interview.

\section{RESULTS AND DISCUSSION}

\section{Study actors}

The dieticians were females aged 22 to 52 years. They had been working at the Regional Education Administrations from 2 months to 2 years. Seven teachers were females and one was male. They were aged 32 to 45 years, had a degree in Letters, Mathematics, Biology, or Geography and had been teaching in public state schools from 5 to 18 years. The technical teaching educators were females aged 29 to 54 years and had a degree in Letters, Mathematics, Biology, or Physical Education.

Six thematic categories emerged from their statements:

- Category I. Food and nutrition education as a means of eating correctly: According to the concept of some school educators on food and nutrition education, the biological dimension of food was emphasized as: identify, choose and eat foods that promote health in place of those that cause disease.

"...it is the advice we receive since childhood, the way we should eat, what is good and what is bad for our health... the good foods are those that provide substances necessary for the nutritional aspect... the bad foods are those that harm our health..." (T7).

"...it is essential for the person... one needs to know what to eat... one has to have nutrition education to avoid mistakes that harm his/her body..." (T3).

"...l see advice of how to eat as a way of preventing some diseases in the future, such as diabetes, heart problems and others..." (E6).

This biological view of food and nutrition education ignores the socioeconomic, cultural and hedonic aspects of food. This created a gap in the knowledge of these educators since food and nutrition education has foci that go beyond health promotion and disease prevention 7 . In this sense, food and nutrition education may be capable of helping people recognize the human right of access to a healthy diet and contribute to environmental sustainability, encouraging the adoption of foods that can be produced sustainably and recommends, for example, a pesticide-free production ${ }^{3}$.

- Category II. The purpose of food and nutrition education: to promote healthy eating habits: Food and nutrition education was also identified as an activity that tries to provide knowledge about healthy eating, generating conscious food choices that create healthy eating habits along with physical activity.

"...activity is very important because it helps students to acquire new knowledge about an appropriate and balanced diet..." (D7).

"...healthy eating habit... together with physical activity..." (E4).

Food and nutrition education in school focused on the process of nutrition re-education, aiming to contribute to current and future health and thereby, to better quality of life.

\footnotetext{
"...food and nutrition education in school is more focused on... providing nutrition education to our children so that in the future their health is not harmed... not only in the future but also during their youth..." (D6).

"...this food and nutrition education in school is based on choosing food groups with your health in mind..." (E5).

"...once you eat well, you have disposition, better reasoning, work better, live longer..." (P2).
} 
These findings corroborate Carvalho et al. ${ }^{17}$ who claims that the objective of food and nutrition education is to create healthy food and life habits.

Healthy eating was understood as the access to and intake of foods that meet the principles of nutrition, prioritizing regional and fresh foods produced without pesticides.

"...healthy eating has to obey four points: amount, quality, harmony and suitability... in the daily routine, one has access to and eats each food group in a complete and varied way... should have a higher amount of fresh foods..." (D9).

"...to have a healthy diet... is to look for the highest number of products that are produced in a healthier way, without pesticides..." (T8).

"...try to make people aware so that they can eat better according to the eating habits of each region..." (D4).

In the participants' view, the concept of a healthy diet considers the nutritional, environmental, and cultural aspects of eating and excludes the psychosocial and affective dimensions consisting of values, choices, and relationships that permeate the act of eating, important for the multidimensional understanding of eating ${ }^{2}$. Therefore, to implement food and nutrition education through a problematizing educational process, one must consider the context of the educators, their aspirations and previous knowledge ${ }^{10}$.

The Guia Alimentar para a População Brasileira (Brazilian Food Guide) presents principles that create a concept for a healthy diet: food in appropriate amount and quality, attractive, varied, physically accessible, affordable, containing highly nutritious foods, preferably fresh, in accordance with the local food habits, produced and consumed locally, and meeting sanitary and hygienic aspects since sowing, and the affective aspects of the human being ${ }^{18}$.

It is noteworthy that the food guide emphasizes the biological aspects of a healthy diet in detriment of the other aspects and exposes what is known about food prescriptively. In this sense, to think about food and nutrition education from the healthy diet approach, whose knowledge is already established, is to adopt a traditional education process in which it is up to the student to assimilate the information ${ }^{10}$.

- Category III. The school: an environment that promotes and enhances food and nutrition education: The school was considered a privileged environment for promoting food and nutrition education, where the role of the teacher and dietician and the students' ages are favorable points for the creation of lifelong healthy eating habits.

\footnotetext{
"...nutrition education is a way to take a healthier diet to the children..." (D2).

"...food and nutrition education at school... with teachers teaching..." (D1).

"...it should be worked at school because food habits are established during childhood... and will last until adulthood..." (D11)
}

In this context, the study actors restated that the school is an environment that structures the development and learning of food and nutrition education. The school is partially responsible for establishing the knowledge and behaviors related to this theme since it has all the learning dimensions regarding teaching and the relationships between family and community ${ }^{4}$.

According to the study participants, food and nutrition education has only recently begun to consolidate in this environment due to the existence of school food and of a dietician in charge of the PNAE.

\footnotetext{
"...lately the dieticians... are concerned with the students eating properly..." (T1).

"...this hiring of people from the area (dieticians) to see the issue of nutrition, what is essential to the children... this concern is always being informed at the schools..." (E7).
} 
The PNAE establishes that all students have the right to a healthy diet at school, contributing to the establishment of healthy eating habits ${ }^{5}$. The participants reported this function of the program when they stated that school food is now healthier.

"...food here at the students' school, food is healthy..." (T6).

"...we observe... a healthier diet in schools..." (E1)

School food was perceived as a food and nutrition education strategy capable of improving students' learning.

"...it is the objective... better student performance... to learn..." (D12).

Hence, it is clear that food and nutrition education at school is related mainly to nutritional issues. Food and nutrition education with this focus has been approached in some school intervention studies, which saw students change their dietary habits in short periods of time, increasing their intake of fruits and vegetables and decreasing their intake of fast foods and soda ${ }^{19,20}$.

- Category IV. Food and nutrition education as a pedagogical practice centered on the student's food reality: Some participants of this study overcame the biological and traditional perception of food and nutrition education that aims to change eating habits. Thus, the concern for approaching the student's reality through food and nutrition education to build knowledge on foods and diet emerged. According to these actors, the educational process of food and nutrition education requires the skill to talk about this knowledge with students, based on the student's food context of access to food, making learning easier and aiming to establish and improve food habits.

"...it is a pedagogic education process... for the establishment of food habits..." (D13).

"...I know the content... but knowing how to transmit the content to them in a way that they understand... then you have to have a way to do it through drawings, group dynamics and conversations, their own testimonies... because they learn it more easily..." (D8).

"...they (students) often stop eating healthier foods... because they don't have information, knowledge..." (D3).

"...When we do not have proper access to foods, we have to improvise, and in nutrition, we have to find ways to adjust the diet to the reality of each group..." (D10).

Therefore, food and nutrition education is not valid when it is presented in the traditional education manner.

"...does education boil down to talk, talk, talk, talk? I think that depositing in the student's mind that banking education of which Paulo Freire talks about... What is a healthy diet? What is important for me to eat? And not taking into consideration what students say, their dietary habits, their financial means, their reality... it is not very valid..." (D1).

Food and nutrition education regarded as a pedagogical practice based on the dietary reality of the students can be based on the liberating education theory. Here, the educator aims to overcome the normalization of knowledge transmission in order to establish the dialogue and criticality that can help to build knowledge, develop awareness, and motivate students to change reality ${ }^{10,21}$.

Some studies describe as successful the experiences associated with providing food and nutrition education through problematizing education, since the latter gives students and educators a contextualized understanding of the dietary, nutritional, and health aspects existent in society ${ }^{22,23}$. Thus, the knowledge built by this education may help to promote the food and nutrition security of children and adolescents ${ }^{24}$.

- Category V. School actors' attributions and partnerships for food and nutrition education: 
298 | AG ALBUQUERQUE et al.

Food and nutrition education should be approached transversally by the disciplines.

"...the issue of transversality would be... teachers trying to approach it through their disciplines..." (D13).

However, one of the educators mentioned that this should be approached by the dietician.

"...this assignment really belongs to a dietician, but we can cooperate, contribute for this to really happen..." (E2).

At the same time, a biology teacher pointed out that food and nutrition education is essential and should be approached by her in school.

"... as a teacher in the area... of biology, it is a bit more exciting, so I believe it is important for us to warn the students... about nutrition (emphasis)..." (T4).

Science teachers can help to identify curricular contents related to nutrition and go ahead and combine these contents with the reality of the students during class $^{24}$.

An educator stated that the exercise of food and nutrition education in school should involve the participation of teachers, dieticians, school principals and cooks.

"...it needs to be a partnership, the teacher, cook, principal, nutrition team..." (E3).

From this statement comes the hope that professionals will participate and join forces for the interdisciplinary construction of food and nutrition education. Interdisciplinarity in food and nutrition education requires these actors to join forces in order to combine the school curriculum disciplines with themselves and with the daily food reality. Dieticians and educators consider the possibility of developing an interdisciplinary work at school and thereby become partners in the promotion of food and nutrition education.

Teachers emerge as the main knowledge disseminators and doers of actions capable of arousing students' interest and participation because they communicate similarly, spend more time with the students and are part of the students' daily routine $e^{4,25}$. They need to go beyond the understanding of their academic degree and turn into professionals with a complete view of reality, acquiring concepts that associate their academic area with other sciences, such as nutrition science ${ }^{26}$.

Therefore, dieticians understand that teachers may work food and nutrition education at school transversely to the disciplines. Transversality is placed in the PCN as the guide for the insertion of themes, such as food and nutrition, in the planning of various disciplines ${ }^{8,9}$. But this guidance is not enough for the interdisciplinary approach of food and nutrition education. Teachers and dieticians need to be aware and trained on this theme ${ }^{20}$.

- Category VI. Lack of knowledge for the practice of food and nutrition education: Dieticians learn the theory of food and nutrition education in college, but the practice was acquired as they practiced their profession.

"...we see in college... a bit about the food groups, a balanced plate, how you should build a balanced plate... approaching the four food groups... . This is how I see nutrition education..." (D5).

"...I know the theoretical part better... and now that I am working, I would see more of the practice, but I knew very little..." (D6).

Some school teachers mentioned not knowing about food and nutrition education and so they feared working the theme.

"...In reality, I know nothing..." (T5).

"...basically nothing, I know there is a dietician responsible for the school food, but I do not participate at all in this, I do not know anything about this area..." (T3).

"...we fear getting lost in the content... wanting to teach something that we have not been taught... and lose focus..." (T8). 
These statements indicate that the lack of knowledge about food and nutrition education is a limitation for providing it. Perhaps this is due to the fact that a teacher's education does not include the subject or is limited to the immediate and technical issues of the discipline, and to the insecurity of approaching a yet little disseminated theme in school.

Nutrition courses need to associate theory and practice for working food and nutritional education in schools; otherwise, dieticians' education and work will be centered on the traditional technical biomedical intervention model, which focuses on disease in detriment of health and its context ${ }^{27}$.

Education within the biomedical model limits dieticians' exercise of food and nutrition education, since dieticians need to follow Resolution 465/201028. This set of rules establishes the assignments of dieticians regarding food and nutrition education for schools, linked to pedagogic managers and coordinators for the planning of activities that include ecologic and social dietary issues. Therefore, it must involve the whole school community ${ }^{29}$.

\section{CONCLUSION}

Educators and dieticians perceived food and nutrition education in two ways: at times as a traditional education aiming at the consumption of foods that prevent diseases and promote health and healthy eating habits, and at other times as a problematizing education centered on the dietary reality of the student, building dietary knowledge that help to make correct food choices. They consider themselves partners for providing food and nutrition education at school, opening way for the development of interdisciplinarity.

However, there are still some gaps in the knowledge of these actors regarding the integration of food and nutrition education with food dimensions. But it is possible to justify this understanding, since they, especially dieticians, have a fragmented professional and scientific education history, based on a biomedical model that confines human beings and society to a reductionist view. Therefore, they find it hard to express a multidimensional knowledge of food, and consequently, of food and nutrition education.

Thus, the multidimensional and interdisciplinary knowledge of food and nutrition education needs to be built together with these actors and be based on their insertion in the social context, aiming to have it recognized as a human right. In this way, understanding the dimensions of diet and food and nutrition security can improve the quality of life of the school community and society.

\section{CONTRIBUTORS}

All authors participated in the study conception, data analysis and interpretation and development of the article. AG ALBUQUERQUE was also responsible for performing the field work and data collection

\section{REFERENCES}

1. Santos LAS. Educação alimentar e nutricional no contexto da promoção de práticas alimentares saudáveis. Rev Nutr. 2005; 8(5):681-92. doi: 10.15 90/S1415-52732005000500011.

2. Castro IRR, Castro LMC, Gugelmim A. Ações educativas, programas e políticas envolvidos nas mudanças alimentares. In: Diez-Garcia RW, CervatoMancuso AM, organizadores. Mudanças alimentares e educação alimentar e nutricional. Rio de Janeiro: Guanabara Koogan; 2011.

3. Boog MCF. Contribuições da educação nutricional à construção da segurança alimentar. Saúde Rev. 2004 [acesso 2012 jan 17]; 6(13):17-23. Disponível em: <http://www.unimep.br/phpg/editora/revistas pdf/saude13art02.pdf>.

4. Bizzo MLG, Leder L. Educação nutricional nos parâmetros curriculares nacionais para o ensino fundamental. Rev Nutr. 2005; 18(5):661-7. doi: 10.1590/S1 415-52732005000500009.

5. Brasil. Ministério da Educação. Resolução/FNDE/CD n 38, de 16 de julho de 2009. Brasília: MS; 2009 [acesso 2010 abr 5]. Disponível em: <http://www. fnde.gov.br/index.php/ae-legislacaos. 
300 | AG ALBUQUERQUE et al.

6. Brasil. Ministério da Educação. Lei $n^{\circ} 11.947$, de 16 de junho de 2009. Brasília: MEC; 2009 [acesso 2010 abr 5]. Disponível em: <http://www.fnde. gov.br/index.php/ae-legislacao>.

7. Brasil. Ministério da Saúde. Portaria $n^{\circ} 2.715$, de 17 de novembro de 2011. Brasília: MS; 2011 [acesso 2011 jul 30]. Disponível em: <http:// nutricao.saude.gov.br/publicacoes.php>

8. Brasil. Ministério da Educação. Parâmetros curriculares nacionais: introdução aos parâmetros curriculares nacionais. Brasília: MEC; 1997. v1.

9. Brasil. Ministério da Educação. Parâmetros curriculares nacionais: apresentação dos temas transversais e ética. Brasília: MEC; 1997. v8.

10. Freire P. Pedagogia do oprimido. $48^{a}$ ed. Rio de Janeiro: Paz e Terra; 2005.

11. Domene SMA. A escola como ambiente de promoção da saúde e educação nutricional. Psicol USP. 2008; 19(4):505-17. doi: 10.1590/S0103-656 42008000400009.

12. Minayo MCS. O desafio do conhecimento: pesquisa qualitativa em saúde. São Paulo: Hucitec; 2008.

13. Instituto Brasileiro de Geografia e Estatística. Sinopse do Censo Demográfico 2010 Pernambuco. Machados - PE. Brasil: situação em 2010. Brasília: IBGE; 2010 [acesso 2011 nov 12]. Disponível em: $<$ http://www.ibge.gov.br/cidadesat/link.php? codmun=260910>

14. Minayo MCS. Ciência, técnica e arte: o desafio da pesquisa social. In: Minayo MCS, Deslandes AF, Gomes R. Pesquisa social, teoria, método e criatividade. 28 ed. Petrópolis: Vozes; 2009.

15. Bardin L. Análise de conteúdo. Lisboa: Edições 70; 2011.

16. Brasil. Ministério da Saúde. Resolução CNS n 196, de 10 de outubro de 1996. Dispõe sobre as diretrizes e normas regulamentadoras de pesquisas envolvendo seres humanos. Brasília: Conselho Nacional de Saúde; 2010 [acesso 2010 jun 12]. Disponível em: <conselho.saude.gov.br/resolucoes/ 1996/reso196.doc>.

17. Carvalho AP, Oliveira VB, Santos LC. Hábitos alimentares e práticas de educação nutricional: atenção a crianças de uma escola municipal de Belo Horizonte, Minas Gerais. Pediatria. 2010 [acesso 2011 nov 13]; 32(1):20-7. Disponível em: <http:// regional.bvsalud.org/php/index.php $>$.

18. Brasil. Ministério da Saúde. Guia alimentar para a população brasileira: promovendo a alimentação saudável. Brasília: MS; 2006.

19. Souza EA, Barbosa Filho VC, Nogueira GAD, Azevedo Júnior MR. Atividade física e alimentação saudável em escolares brasileiros: revisão de programas de intervenção. Cad Saúde Pública. 2011; 27(8):1459-71. doi: 10.1590/S0102-311X201100 0800002 .
20. Vargas ICS, Sandre-Pereira RSG, Veiga GV. Avaliação de programa de prevenção de obesidade em adolescentes de escolas públicas. Rev Saúde Pública. 2011; 45(1):59-68. doi: 10.1590/S0034-89102 011000100007.

21. Caniné ES, Ribeiro VMB. A prática do nutricionista em escolas municipais do Rio de Janeiro: um espaço-tempo educativo. Ciênc Educ. 2007; 13(1): 47-70. doi: 10.1590/S1516-73132007000100 004.

22. Rodrigues EM, Boog MCF. Problematização como estratégia de educação nutricional com adolescentes obesos. Cad Saúde Pública. 2006; 22(5): 923-31. doi: 10.1590/S0102-311X2006000500 005.

23. Manço AM, Costa FNA. Educação nutricional: caminhos possíveis. Alim Nutr. 2004 [acesso 2010 abr 26]; 15(2):145-53. Disponível em: <http://servbib.fcfar.unesp.br/seer/index.php/alimentos>.

24. Verde SMML, Olinda QB. Educação nutricional: uma ferramenta para alimentação saudável. Rev Bras Promoç Saúde. 2010 [acesso 2012 jan 11]; 23(3): 197-8. Disponível em: <http://regional.bvsalud.org/ php/index.php>

25. Bernadon R, Silva JRM, Cardoso GT, Monteiro RA, Amorim NFA, Schmitz BAS, et al. Construção de metodologia de capacitação em alimentação e nutrição para educadores. Rev Nutr. 2009; 22(3): 389-98. doi: 10.1590/S1415-52732009000300 009.

26. Thiesen JS. A interdisciplinaridade como um movimento articulador no processo ensino-aprendizagem. Rev Bras Educ. 2008; 13(39):545-54. doi: 10.1590/S1413-24782008000300010.

27. Santos LAS. O fazer educação alimentar e nutricional: algumas contribuições para a reflexão. Ciênc Saúde Coletiva. 2012; 17(2):453-62. doi: 10.1590/ S1413-81232012000200029.

28. Brasil. Conselho Federal de Nutricionistas. Resolução $n^{\circ} 465$, de 25 de agosto de 2010. Dispõe sobre as atribuições do nutricionista, estabelece parâmetros números mínimos de referencia no Programa de Alimentação Escolar (PAE) e dá outras providencias. Brasília: Conselho Federal de Nutricionistas; 2010 [acesso 2010 nov 20]. Disponível em: <http://www.fnde.gov.br/index.php/aelegislacao>.

29. Piccoli L, Johann R, Corrêa EN. A educação nutricional nas séries iniciais de escolas públicas estaduais de dois municípios do oeste de Santa Catarina. Nutrire. 2010 [acesso 2011 nov 13]; 35(3): 1-15. Disponível em: <http://regional.bvsalud.org/ php/index.php>.
Received on: 22/6/2012

Final version on: 14/11/2012 Approved on: 9/1/2013 